\author{
Anna Michalska \\ ORCID: 0000-0003-2163-4718 \\ Uniwersytet Wrocławski
}

\title{
Nowe perspektywy w badaniach nad nowożytnymi albumami przyjaźni*
}

Abstrakt: Celem artykułu, opartego na badaniach nad sztambuchami (alba amicorum, albumy przyjaźni) w zbiorach Biblioteki Uniwersyteckiej we Wrocławiu, jest zaprezentowanie nowych perspektyw badawczych dla tego rodzaju rękopisów. Autorka zarysowuje krótko historię albumów przyjaźni oraz stan badań, skupiając się na przyjętych przez badaczy metodach i podjętych tematach. W kolejnych częściach artykułu sztambuchy są przedstawione jako „przedmioty i elementy sieci”, „kolekcje” i "performensy”. Pierwsza z nich, odnosząc się do powrotu do materialności i idei sprawczości rzeczy, prezentuje alba amicorum jako materialne jednostki (a nie tylko nośniki informacji czy dzieł sztuki), zwracając również uwagę ich aktywną rolę w tworzeniu i podtrzymywaniu sieci społecznych. Część zatytułowana Kolekcja prezentuje ujęcie, w którym każdy sztambuch jest jednocześnie kolekcją (autografów, obiektów wizualnych, cytatów) oraz przedmiotem kolekcjonerskim. Albumy przyjaźni gromadzone w muzeach i bibliotekach tracą dziś swój performatywny charakter, opisany w ostatniej części opracowania.

Słowa-klucze: sztambuchy, albumy przyjaźni, alba amicorum, Śląsk

Badania nad sztambuchami mają długą historię — pierwsza poświęcona im rozprawa opublikowana została jeszcze w XVIII wieku' ${ }^{1}$. Nie była ona oczywiście dziełem naukowym sensu stricto, ale najstarszą próbą zdefiniowania i opisania zjawiska. Trudno się dziwić zainteresowaniu tematem — rękopisy te niemal całą epokę nowożytną pozostając domeną dość elitarnych kręgów, nierzadko zawierały treści wysublimowane pod względem intelektualnym czy artystycznym. Z zachowanych źródeł wiemy, że do ich tworzenia przykładano wielką wagę, a nie dość wyszukany i dopracowany wpis ofiarowany właścicielowi albumu mógł stać się powodem ogromnego zaambarasowania jego autora ${ }^{2}$. Po śmierci właściciela

\footnotetext{
* Artykuł powstał w czasie zajęć z prof. Renatą Tańczuk, której dziękuję za cenne uwagi i sugestie.

${ }^{1}$ M. Lilienthal, Schediasma critico-literarium de philothecis varioque earundem usu et abusu, vulgo von Stamm-Büchern, Leipzig 1712.

${ }^{2}$ Zob. M. Nickson, Some Early English, French and Spanish Contributions to Albums, [w:] Stammbücher des 16. Jahrhunderts, red. W. Klose, Wolfenbüttel 1989, s. 65.
} 
sztambuchy przechowywano w rodzinie lub w innych prywatnych zbiorach. Dziś większość tych obiektów znajduje się w bibliotekach i muzeach, gdzie wydziela się je często jako osobną kategorię w katalogach tematycznych i często jako takie kolekcje poddaje naukowej refleksji.

W oparciu o swoją pracę z nowożytnymi obiektami tego rodzaju w zbiorach Biblioteki Uniwersyteckiej we Wrocławiu chciałabym ukazać główne problemy podejmowane w dotychczasowych badaniach oraz wskazać możliwe dalsze ich perspektywy, przede wszystkim te związane z nowymi nurtami badawczymi w humanistyce.

\section{Sztambuch — zarys historii zjawiska}

Czym właściwie jest sztambuch? W pierwotnym znaczeniu niemieckie Stammbuch określało pamiątkową księgę rodzinną, wywód szlacheckich przodków, tekstowy odpowiednik graficznego Stammbaum (niem. Stamm — pień, plemię) czy Ahnentafel ${ }^{3}$. Sztambuchy związane były więc z porządkiem pokrewieństwa i powinowactwa, podobnie jak tak zwane biblie rodzinne (niem. Familienbibeln), zawierające kronikę ważnych wydarzeń, głównie narodzin, małżeństw i śmierci członków rodu ${ }^{4}$.

Sztambuchy, którym chcę się bliżej przyjrzeć — inaczej albumy przyjaźni (łac. alba amicorum) czy filoteki (gr./łac. Philothecae) — narodziły się w XVI wieku w środowisku akademickim Wittenbergi i dość szybko rozpowszechniły w krajach niemieckich ${ }^{5}$. W połowie stulecia pierwsze albumy zakładali mieszkańcy Niderlandów i Anglií.

Służyły one uzyskiwaniu wpisów — od prostych podpisów po rozbudowane, wieloczęściowe inskrypcje, nierzadko z miniatorską dekoracją — początkowo osób spotkanych w czasie akademickich peregrynacji czy grand tour, przede wszystkim profesorów i innych autorytetów, z czasem również kolegów, członków rodziny, przedstawicieli tej samej grupy społecznej czy zawodowej, mecenasów i innych. Według słów przypisywanych jednemu z czołowych ówczes-

${ }^{3}$ Zob. J. Grimm, W. Grimm, Stammbuch, [w:] Deutsches Wörterbuch, Leipzig 1919, t. 17, szp. 647; W.W. Schnabel, Das Stammbuch. Konstitution und Geschichte einer textsortenbezogenen Sammelform bis ins erste Drittel des 18. Jahrhunderts, Tübingen 2003, s. 285.

${ }^{4}$ Wiedzę o nich czerpię z wystąpienia Marii Deiters pt. „Familienbibel, Geschlechterbuch und Bild. $\mathrm{Zu}$ neuen Formen familiärer Gedächtnisstiftung und memorialer Bildkomplexe im Reformationsjahrhundert", wygłoszonego w czasie konferencji RefoRC w Berlinie 16 maja 2013 roku.

5 Jest to jedna z koncepcji ich genezy, najpowszechniej obecnie przyjmowana, por. W.W. Schnabel, op. cit., s. 244.

${ }^{6}$ Zob. M. Nickson, op. cit. 
nych teologów, Filipowi Melanchtonowi ${ }^{7}$, wartość albumów przyjaźni polegała na upamiętnieniu osób, przekazywaniu inspirujących myśli i nauk, a wreszcie utrwalaniu pozytywnego obrazu właściciela albumu w postaci pochwał, z których czerpać mógł on przez całe późniejsze życie.

Pierwsze sztambuchy prowadzono na wolnych kartach drukowanych książek, zwłaszcza ksiąg emblematycznych, przygotowywanych zresztą niekiedy specjalnie $\mathrm{z}$ większą liczbą pustych stronic. Taką formę ma najstarszy zachowany we wrocławskich zbiorach album, użytkowany w latach 1567-1576 przez Johanna Reimanna ${ }^{8}$, spisany na kartach dwóch współoprawnych druków, między innymi księgi emblematycznej Andrei Alciatiego.

Najpopularniejszą formą sztambucha stał się niewielkich rozmiarów — ze względu na wygodę przenoszenia — kodeks, o kartach czystych bądź wypełnionych rękopiśmiennym lub drukowanym schematem dekoracji, na przykład konturami tarczy herbowej czy banderolą, na której wpisujący się powinien umieścić swoje motto. Wpisowi towarzyszyć mogła miniatura zamawiana u jednego z tak zwanych Briefmalern ${ }^{9}$ lub amatorska, wklejona grafika bądź jej fragment, a później także papierowa wycinanka lub haft. Tematyka przedstawień, zwłaszcza w kręgach studenckich, była często frywolna: studenckie zabawy, rywalizacja o względy panien i kawalerów, nagie lub półnagie kobiety. Powstawały też słowne lub obrazowe programy moralizatorskie, o charakterze religijnym, portrety autorów wpisów, widoki miast i posiadłości, a wreszcie różnego rodzaju wizualizacje żywionego do właściciela albumu uczucia przyjaźni ${ }^{10}$.

\section{Tradycyjne podejścia w badaniach nad wrocławskimi sztambuchami}

Wobec niezbyt obszernej literatury przedmiotowej dotyczącej sztambuchów ze zbiorów BUWr łatwo można wskazać tematy najczęściej przyciągające dotychczas uwagę badaczy. Były to sztambuchy i poszczególne wpisy cenne ze

${ }^{7}$ Zob. R. Keil, R. Keil, Die deutschen Stammbücher des sechzehnten bis neunzehnten Jahrhunderts, Berlin 1893, s. 9; W.W. Schnabel, op. cit., s. 253.

8 Zob. A. Borys, Album Amicorum Johanna Reimanna (1544-1597). Najstarszy znany sztambuch w zbiorach Biblioteki Uniwersyteckiej we Wrocławiu, [w:] Ślaska republika uczonych, red. M. Hałub, A. Mańko-Matysiak, Dresden-Wrocław 2012, s. 109-128.

9 T. Kohlmann, Modelstecher, Briefmaler, Illuministen und Kartenmaler, [w:] Lexikon des alten Handwerks, red. R. Reith, München 1990, s. 164-167.

${ }^{10}$ Zob. na przykład L. Kurras, Stammbücher: Freundschaft in Wort und Bild, [w:] Freundschaft. Motive und Bedeutungen, red. S. Appuhn-Radtke, E. Wipfler, München 2006. 
względu na badania biograficzne i heraldyczne ${ }^{11}$, wpisy w konkretnym języku ${ }^{12}$, a także obiekty bogato dekorowane ${ }^{13}$, zwłaszcza o dekoracji emblematycznej ${ }^{14}$. Opracowania najczęściej nie zajmowały się więc wszystkimi dostępnymi obiektami, a tylko albumami lub ich fragmentami wybranymi pod kątem określonego problemu. Prace obejmujące większą liczbę obiektów — bez wyjątku kilkunasto- lub kilkudziesięciostronicowe artykuły — z konieczności traktowały materiał dość ogólnie ${ }^{15}$.

Takie sprofilowanie badań wynika, jak się wydaje, ze wciąż niesatysfakcjonującego stopnia rozpoznania śląskiego materiału zabytkowego, co sprawia, że w literaturze przedmiotu dominują prace wprowadzające dane obiekty lub pewne ich części do dyskursu naukowego. Albumy są opracowane pod kątem bibliotekoznawczym, częściowo posiadają też dokumentację konserwatorską, uwzględniającą między innymi rodzaj zniszczeń czy brakujące karty.

Niewiele albumów ze zbiorów BUWr zostało uznanych za na tyle istotne dla obrazu epoki, że doczekały się monograficznego opracowania, pozwalającego na szerokie, wieloaspektowe przyjrzenie się jednemu albumowi. Największe zainteresowanie badaczy wzbudziły bodajże te należące do rodziny Maiorów ${ }^{16}$, wspomnianego już Reimanna ${ }^{17}$, poety Christiana Hoffmanna von Hoffmanswaldau ${ }^{18}$ czy — z późniejszych albumów — ten należący do pierwszego dyrektora wrocławskiej Szkoły Sztuk Pięknych, Carla Daniela Friedricha Bacha ${ }^{19}$.

${ }^{11}$ E. Białek, W. Mrozowicz, Die Eintragungen von August Buchner in den Stammbüchern der Universitätsbibliothek Wroclaw, ,Wolfenbütteler Barocknachrichten” 14, 1987, s. 68-71.

${ }^{12}$ E. Białek, Polnische Einträge in den Stammbüchern der Universitätsbibliothek Wroclaw, „Germanica Wratislaviensia” 68, 1985, s. 111-132; S. Kiedroń, Neerlandicauit de kring van Martin Opitz (1597-1639), „Colloquium Neerlandicum” 12, 1994, s. 153-164.

13 P. Oszczanowski, J. Gromadzki, Theatrum vitae et mortis. Grafika, rysunek i malarstwo ksiażkowe na Śląsku w latach ok. 1550 - ok. 1650, Wrocław 1995.

${ }^{14}$ C. Schwarz, Das Album amicorum als Ort für Produktion und Rezeption von Emblemen. Überlegungen zu drei Stammbüchern (1639-1652) der Familie Maior aus Breslau, [w:] Polyvalenz und Multifunktionalität der Emblematik II, red. W. Harms, D. Peil, Frankfurt am M. 2002, s. 907-929.

15 E. Volger, Ueber die Sammlung von Stammbüchern (77 Stück) in der Stadtbibliothek zu Breslau, ,Schlesiens Vorzeit in Bild und Schrift” 3, 1881, s. 445-475; E. Volger, Katalog der Stammbücher der Stadtbibliothek Breslau, t. 1, rkps, bez daty, sygn. akc. 1967 KN 11; K. Masner, Die schlesischen Stammbücher und ihre künstlerische Ausschmückung, ,Jahrbuch des Schlesischen Museums für Kunstgewerbe und Altertümer" 4, 1907, s. 137-170; I. Banet, M. Szyrocki, Die Stammbücher der Universitätsbibliothek Wrocław des 16. bis 18. Jahrhunderts, [w:] Stammbücher als kulturhistorische Quellen, red. J.-U. Fechner, München 1981, s. 65-71; E. Białek, Die Stammbuchsammlung in der Universitätsbibliothek Wroclaw, „Germanica Wratislaviensia” 68, 1985, s. 133-146.

${ }^{16}$ C. Schwarz, op. cit.

17 A. Borys, op. cit.

18 E. Białek, Das Stammbuch des Dichters Christian Hoffmann von Hoffmannswaldau, „Daphnis" 16,1987, s. 441-456.

19 Zob. C. Schwarz, op. cit.; T. Windyka, Carl Daniel David Friedrich Bach. Jego życie i dziatalność. Sztambuch artysty, mps, Wrocław 1982. 


\section{Sztambuch jako przedmiot i element sieci}

W dotychczasowych badaniach prowadzonych na wrocławskim materiale $\mathrm{z}$ albumów przeważnie „wycina się” pojedyncze ich fragmenty — takie jak szczególnie rozbudowaną dekorację poszczególnych wpisów, przedstawienia słowno-obrazowe, określonego rodzaju teksty - a następnie analizuje je w oderwaniu od albumu jako materialnego obiektu. Brakujące karty, rodzaj (a więc i geneza) uszkodzeń, a nawet oprawa i papier pozostają w obrębie zainteresowań niemal wyłącznie konserwatorów czy nielicznych badaczy w tych tematach się specjalizujących ${ }^{20}$.

Nie jest to $\mathrm{w}$ żadnym razie metoda naganna sama w sobie, zaciera jednak fakt, że sztambuch jest materialną całością, chociaż powstałą w efekcie długotrwałego procesu, metodą nawarstwień, a nie ,jedynie” nośnikiem treści — „gdy chodzi o rzeczy będące nośnikami tekstów, teksty niemal całkowicie przesłaniają rzeczowość" 21 .

Tymczasem z perspektywy ,powrotu do rzeczy” czy „powrotu do materialności”, podkreślającego ,aktywność” przedmiotów oraz ich integralny udział w stosunkach międzyludzkich ${ }^{22}$, to właśnie połączenie tych dwóch nurtów badań pozwoliłoby na pełniejsze zrozumienie poddawanych refleksji obiektów. W efekcie można by pokusić się o stworzenie „,biografii” ${ }^{23}$ poszczególnych albumów, jakże odmiennych od biografii ich ,właścicieli” i autorów poszczególnych wpisów, dotąd w badaniach nad wrocławskimi rękopisami faworyzowanych.

Bez wątpienia sztambuchy stanowiły element nowożytnych sieci społecznych: transgranicznej Republiki uczonych, sieci kontaktów naukowych i handlowych. Jeśli w kategorii wewnętrznie złożonych sprawców rozpatrywać również instytucje w rodzaju uniwersytetu czy organizacji kościelnych bądź cechów, a także grupy językowe czy wyznaniowe ${ }^{24}$, na jaw wychodzi złożoność relacji, w które wchodziły badane obiekty. Adam Smyth w recenzji książki June Schlueter ${ }^{25}$ opisuje fenomen sztambuchów jako dziennik podróży (travelogue), zawierający ilustracje odpowiadające dzisiejszym snapom (snaps) i za pomocą na wskroś

${ }^{20}$ Do wyjątków należą badania T. Windyki, op. cit.

${ }^{21}$ P. Rodak, Rzeczy w kontekście pisania. O materialności dzienników osobistych, „Kultura Współczesna" 2008, nr 3, s. 101.

${ }^{22}$ R. Tańczuk, Ars colligendi. Kolekcjonowanie jako forma aktywności kulturalnej, Wrocław 2011, s. 76; E. Domańska, Problem rzeczy we współczesnej archeologii, [w:] Rzeczy i ludzie. Humanistyka wobec materialności, red. J. Kowalewski, W. Piasek, M. Śliwa, Olsztyn 2008, s. 43.

23 Termin wprowadzam za: I. Kopytoff, Kulturowa biografia rzeczy - utowarowienie jako proces, [w:] Badanie kultury. Elementy teorii antropologicznej, przeł. E. Klekot, red. M. Kempny, E. Nowicka, Warszawa 2003, s. 249-274.

${ }^{24}$ M. Ryantová, Konfessionelle und konfessionsübergreifende Netzwerke in Stammbüchern der Frühen Neuzeit, „Berichte und Beiträge des Geisteswissenschaftlichen Zentrums Geschichte und Kultur Ostmitteleuropas an der Universität Leipzig” 2006.

$25 \mathrm{https} / /$ www.the-tls.co.uk/articles/public/social-networking-early-modern-style; por. J. Schlueter, The Album Amicorum and the London of Shakespeare's Time, London 2012. 
współczesnego języka ukazuje albumy przyjaźni jako nowożytne media społecznościowe. Bronwen Wilson pisze o sztambuchach:

they established alternative modes of bringing people together to those of established systems of patronage, thereby creating networks that crossed historical and geographical boundaries, as well as professional ones. [...] More than a material collection of names, the volumes recorded earlier encounters and their attendant negotiations as they solicited new ones ${ }^{26}$.

Zwłaszcza w myśl koncepcji sprawczości rzeczy Brunona Latoura i Alfreda Gella możemy patrzeć na rzeczy nie tylko jako na dokumenty rozlicznych powiązań, ale również ich aktywnych uczestników ${ }^{27}$. Relacje pamiętnikarskie nieliczne, niestety - przekazują informacje o interakcjach, które bez pretekstu w postaci albumu przyjaźni nie mogłyby zaistnieć ${ }^{28}$.

Badanie sztambuchów jako elementów sieci przy pomocy różnych metod ukonstytuowanych na polu nauk społecznych postępować będzie zapewne wraz z rozwojem wieloosobowych projektów i baz danych zbierających rozproszony materiał zabytkowy. Tak więc możliwość zadania pytań z nowego kwestionariusza badawczego uzależniona jest od dostrzeżenia przez badaczy konieczności wykorzystania nowych technologii i współpracy ponad granicami dyscyplin naukowych.

\section{Sztambuch jako kolekcja}

Sztambuch jest bez wątpienia materialnym obiektem, ale jednocześnie — kolekcją, i to kolekcją szczególną, bo stanowiącą zarazem przedmiot kolekcjonerski.

W badaniach nad sztambuchami niezbędne wydaje się uwzględnienie doświadczeń badań nad kolekcjami i nad kolekcjonowaniem. Nie przypadkiem pojawienie się sztambuchów zbiega się w czasie z początkami nowożytnego kolekcjonerstwa obiektów współczesnych ${ }^{29}$. Jeśli za Susan Pearce uznamy kolekcję za „specjalny zbiór przedmiotów będący rezultatem procesu selekcji”, zbudowany w oparciu o ,intencję stworzenia grupy materiału”, a jej elementy za „zreifikowane myśli i uczucia"30 — sztambuchy zdecydowanie podpadają pod tę definicję.

${ }^{26}$ B. Wilson, Social Networking. The "Album amicorum" and Early Modern Public Making, [w:] Beyond the Public Sphere. Opinions Publics, Spaces in Early Modern Europe, red. M. Rospocher, Bologna 2012. Analizę pod tym kątem sztambucha Samuela Reiche (Akc. 1949/1032) z kolekcji BUWr przeprowadziła Dąbrowska-Burkhardt (2016).

27 Zob. B. Latour, Where Are the Missing Masses? Sociology of a Few Mundane Artefacts, [w:] Technology and Society, Building Our Sociotechnical Future, red. D. Johnson, J. Wetmore, Cambridge 2008, s. 151-180.

28 B. Wilson, op. cit., s. 214.

29 R. Tańczuk, op. cit., s. 111.

30 Ibidem, s. 141-142. 
Albumy przyjaźni łączą (w różnych proporcjach) trzy rodzaje kolekcji: 1) zbiór autografów osób bliskich lub autorytetów, 2) zbiór obiektów wizualnych oraz 3) zbiór stymulujących intelektualnie czy uwrażliwiających moralnie tekstów, nierzadko wykorzystujących rebusy, emblematy, gematrię, gry słowne itp. W świetle dotychczasowych badań nad wrocławskimi sztambuchami wydaje się, że najwięcej uwagi poświęcono pierwszemu i drugiemu zagadnieniu. Jeśli chodzi o dekorację rysunkową i malarską — podlegała ona jednak właściwemu klasycznej historii sztuki wartościowaniu w kategoriach estetycznych, przez co na analizę zasłużyły przede wszystkim przedstawienia uznane za najlepsze artystycznie ${ }^{31}$. Zapewne z tego względu ogromna liczba głównie osiemnasto- i dziewiętnastowiecznych ilustracji - w przeważającej części amatorskich, uznawanych za „typowe" - nie została nigdy opublikowana ani przebadana ${ }^{32}$.

Sztambuchowe kolekcjonerstwo wszystkich wymienionych wyżej typów było podatne na procesy kulturowe kształtujące inne aktywności konsumpcyjne, opisywane przez Russella Belka, między innymi wzrost produkcji masowej — dostępność gotowych do użycia albumów i związany z nią spadek cen, a także wzrost dostępności gotowych dekoracji znacząco przyczyniły się do egalitaryzacji tego medium $^{33}$.

Spojrzenie na albumy z perspektywy procesu kolekcjonowania (zarówno samych wpisów, jak i — później — całych sztambuchów) pozwoliłoby uniknąć pomijania czy marginalizacji w obrębie dyskursu naukowego zjawisk takich, jak na przykład pojawiające się na kartach albumów już po zakończeniu ich użytkowania dziecięce rysunki ${ }^{34}$ czy ćwiczenia kaligraficzne, obecne $w$ wielu albumach ze zbiorów BUWr. Stanowią one, jak się wydaje, istotne świadectwo funkcjonowania kolekcji, niepoddane jednak jeszcze naukowej refleksji.

\section{Sztambuch jako performens}

Włączenie sztambuchów do kolekcji bibliotecznych i muzealnych spowodowało utratę ich performatywnego charakteru. Wydaje się jednak, że spojrzenie z perspektywy performative turn stanowi szansę na zrozumienie tego ważnego aspektu funkcjonowania albumów.

31 P. Oszczanowski, J. Gromadzki, op. cit.

32 Temat jednego z rodzajów takiej dekoracji podjęłam w artykule Świątynie przyjaźni. Funkcje motywu architektury i rzézby ogrodowej w sztambuchach z przełomu XVIII i XIX wieku na przykładzie zbiorów Biblioteki Uniwersyteckiej we Wrocławiu, „Quart. Kwartalnik Instytutu Historii Sztuki Uniwersytetu Wrocławskiego" 48, 2018, nr 2, s. 22-38.

${ }^{33}$ R. Tańczuk, op. cit., s. 140.

${ }^{34}$ Zob. M. Nickson, op. cit., s. 67. 
Wyraźnym sygnałem zainteresowania badaczy tą tematyką wydaje się opublikowane w 2002 roku studium Christiane Schwarz ${ }^{35}$. Przekonuje o tym już tytuł - badaczka skupia się na Stambuchpraxis, procesie kształtowania i użytkowania albumów, na przykładzie czterech wybranych obiektów. Podobnie ujęty temat pojawia się wprawdzie u Lilienthala (de usu et abusu), dzieło to ma jednak charakter raczej praktyczny, stanowiąc swego rodzaju podręcznik. Schwarz rekonstruuje funkcjonowanie sztambuchów — sposób (i koszt!) ich zamawiania, przekazywania osobie, o której wpis się starano (niekiedy mocno skonwencjonalizowany), częstotliwość powracania do albumu po uzyskaniu wpisu i wiele innych, kładąc nacisk na aspekt procesualności, czasowości.

Rekonstrukcja ta ujawnia rytualizację pewnych zachowań i formuł. Mowa tu o rytuale $\mathrm{w}$ ujęciu właśnie performative turn, rozszerzonym $\mathrm{w}$ stosunku do tradycyjnie przyjętego w etnologii ${ }^{36}$. Rytuały dotyczące sztambuchów związane były ściśle z porządkiem społecznym. Przekazanie albumu powinno odbywać się w określony sposób, a zgoda na wykonanie wpisu mogła oznaczać zgodę na nawiązanie relacji bądź — w wypadku na przykład autografów profesorów — akt rekomendacji właściciela, miała więc doniosłe konsekwencje:

The object reinforced the social connection between giver and recipient, establishing the book as a site of memory, its physical existence recalling various degrees and kinds of invisible links among its owners ${ }^{37}$.

Nie bez znaczenia jest fakt, że albumy u początku swojej historii towarzyszyły młodym ludziom $\mathrm{w}$ akademickich peregrynacjach bądź $\mathrm{w}$ grand tour, podróży edukacyjnej odbywanej pod okiem wykształconego preceptora. W ten sposób stawały się dokumentami przejścia z wieku młodzieńczego w dojrzały i pamiątkami wiodącej do niego drogi. Również w późniejszych sztambuchach grupy wpisów mogą pojawiać się w związku z określonym momentem przełomowym, na przykład z konfirmacją ${ }^{38}$.

Aspekt performatywny mogło mieć też samo przeglądanie albumu. Przyjaciele wpisując się na sąsiednich stronach — co odbiegało od praktyki, nakazującej zostawić odstęp od sąsiedniego wpisu — dodawali często linię tekstu, głoszącą na przykład: „te strony łączą przyjaciół”, umieszczoną po połowie na obu stronicach i łamiącą się na szwie. Powracanie do tak skonstruowanych wpisów oznaczało

35 C. Schwarz, Studien zur Stammbuchpraxis der Frühen Neuzeit. Gestaltung und Nutzung des Album amicorum am Beispiel eines Hofbeamten und Dichters, eines Politikers und eines Goldschmieds (etwa 1550 bis 1650), Frankfurt am M. 2002.

${ }^{36}$ D. Bachmann-Medick, Cultural turns. Nowe kierunki w naukach o kulturze, przeł. K. Krzemieniowa, Warszawa 2012, s. 130-131.

${ }^{37}$ M.C. Erler, The Book of Hours as Album Amicorum: Jane Guildford's Book, [w:] The Social Life of Illumination. Manuscripts, Images, and Communities in the Late Middle Ages, red. J. Coleman, M. Cruse, K.A. Smith, Turnhout 2013, s. 505.

38 G. Angermann, Stammbücher und Poesiealben als Spiegel ihrer Zeit nach Quellen des 18.20. Jahrhunderts aus Minden-Ravensberg, Münster 1971, s. 29. 
każdorazowo „inscenizację” takiej relacji. Inne komunikaty wysyłane kolejnym wpisującym się umieszczano na przykład pod kątem dziewięćdziesięciu stopni lub do góry nogami, co sprawiało, że kolejny wpisujący się lub sam właściciel albumu musieli - czasem kilkukrotnie w czasie czytania - obrócić w rękach album, aby odczytać na przykład toast na swoją cześć. Współcześnie organizowane wystawy albumów przyjaźni prezentują na ekranach bądź w kioskach multimedialnych elementy dekoracji, które przeznaczone były do otwierania, poruszania itd. ${ }^{39}$

Dynamiczny aspekt sztambuchów jawi się wyraźniej, jeśli uświadomimy sobie funkcjonowanie innych ówczesnych poświęconych przyjaźni miejsc. Księżna Anna Zofia Legnicka w swojej wiejskiej rezydencji Sophienthal nakazała wykonanie szczególnej dekoracji — na ścianach umieszczono emblematy ofiarowane jej przez przyjació $1^{40}$. Księżna oprowadzała po takim monumentalnym ,albumie przyjaźni” swoich gości i dwórki, objaśniając sens przedstawień. Również w powstających od XVIII wieku ogrodach krajobrazowych umieszczano miejsca świątynki, ołtarzyki czy kamienie z inskrypcją — poświęcone konkretnym osobom z kręgu przyjacielskiego czy rodzinnego. Być może również na sztambuchy trzeba spojrzeć przez pryzmat czynności przywołującej wspomnienie, procesu odkrywania, odnajdywania, objaśniania ukrytej, zagadkowej treści osobom postronnym.

\section{Zakończenie}

Zainteresowanie nowymi kwestionariuszami badawczymi rodzi wątpliwości, podnoszone przede wszystkim wśród tradycyjnie zorientowanych badaczy. Zastanawiają się oni, na ile faktycznie „nowe” są owe „nowe perspektywy”. Dowodzi się, że te same postulaty i pytania stawiane były już wcześniej, a zacieranie granic dyscyplin przez przeszczepianie metod ukonstytuowanych na innych polach badawczych prowadzi do zamętu i kryzysów ich tożsamości. Co do tego pierwszego, wydaje się, że jeżeli brak satysfakcjonujących odpowiedzi, zasadne jest stawianie na nowo „tych samych” pytań. Nie jest to bynajmniej zarzut pod adresem wcześniejszych badaczy — wraz ze zmieniającymi się perspektywami badawczymi zmienia się też oczekiwana precyzja i dogłębność odpowiedzi.

39 Tak na przykład w wypadku wystawy „„Nicht zum Fressen, nicht zum Saufen, sondern Weisheit einzukaufen...« Hallische Universitätsgeschichte in Stammbücher”, eksponowanej od 17 listopada 2017 do 14 stycznia 2018 w Technisches Halloren- und Salinemuseum w Halle. Katalog wydany pod tym samym tytułem (red. A. Berhaus-Sprengel, Halle [Saale] 2017) zawiera zwielokrotnione zdjęcia takich obiektów.

${ }^{40}$ M. Czarnecka, Dekorative Anwendung der Emblematik am Beispiel von Sophienthalschen Sinnbildern der Herzogin Anna Sophia von Liegnitz (1628-1666), „Daphnis” 23, 1994, z. 1, s. 1-35. Za zwrócenie mojej uwagi na tę publikację dziękuję Wojciechowi Grukowi. 
Co do drugiego - obawy te mają związek raczej z utrwalonym instytucjonalnie i proceduralnie obrazem akademii, a nie dobrem nauki jako takiej.

Niewątpliwie jednak między innymi te właśnie nowe nurty skłaniają do uważnego przyjrzenia się sztambuchom w zbiorach BUWr. Powrót do materialności badanych obiektów i ich funkcjonowania jako kolekcji, uświadomienie sobie ich uwikłania w określone sieci powiązań, a być może także ich sprawczego potencjału — rzuca na nie inne światło. Ten krótki przegląd nie pretenduje przy tym do uwzględnienia wszystkich interesujących perspektyw badań.

Nie zostały uwzględnione chociażby badania genderowe. W śląskich zbiorach zachowały się wprawdzie nieliczne tylko przykłady nowożytnych albumów prowadzonych przez kobiety, ale możliwa byłaby analiza prezentowanych na kartach albumów ról płciowych. W odniesieniu do zachowanych albumów stanowiących własność kobiet, pochodzących bez wyjątku z XVIII wieku, ważne byłoby przeanalizowanie różnic w stosunku do sztambuchów zakładanych przez mężczyzn. Materiał europejski pokazuje, że te pierwsze były częściej owocem odwiedzin gości niż odbytych podróży, obejmowały też znacznie większą liczbę członków rodziny ${ }^{41}$. Warto byłoby także zadać pytanie o istnienie warunkowanych płcią wpisującej się osoby schematów dekoracji ${ }^{42}$.

Nowe perspektywy badawcze, podejścia i paradygmaty często skłaniają do zadawania pytań „o to, czego nie ma”. Hans Belting pytał w ten sposób o anikoniczny ołtarz protestancki, tak zwany ołtarz inskrypcyjny, interpretując go jako ,antyobraz"43. Przedstawiciel młodego pokolenia badaczy, Arnoud Visser, podniósł kwestię „konfesyjnego milczenia” — pozornego przynajmniej braku wyraźnego sprofilowania wyznaniowego w nowożytnych księgach emblematycznych ${ }^{44}$. Podobne pytania należałoby zadać również w odniesieniu do śląskich sztambuchów.

Takie pogłębione, uważne spojrzenie pomaga włączyć nowe metody badań, stawiające badane obiekty w sposób zamierzony w nieoczywistym kontekście, zwracające uwagę na ich inne niż powszechnie uznane funkcje czy zadające inne pytania.

${ }^{41}$ Zob. M.-A. Delen, Frauenalben als Quelle. Frauen und Adelskultur im 16. Jahrhundert, [w:] Stammbücher des 16. Jahrhunderts..., s. 75-94.

42 Istnienie ,typowo kobiecych” za pewnik przyjmował na przykład wybitny znawca sztambuchów skandynawskich Vello Helk (na przykład Stambøger i Det kongelige Bibliotekfør 1800, Copenhagen 1980, s. 142).

${ }^{43}$ H. Belting, Bild und Kult: eine Geschichte des Bildes vor dem Zeitalter der Kunst, München 2000, s. 280. Interpretacja ta, oparta na analizie ołtarza z Dinkelsbühl, spotkała się z uzasadnioną krytyką ze strony Gottschalka Diedricha, Die protestantischen Schriftaltäre des 16. und 17. Jahrhunderts in Nordwestdeutschland, Regensburg 2005.

${ }^{44}$ A. Visser, Escaping the reformation in the Republic of Letters: Confessional silence in latin emblem books, „Church History and Religious Culture” 88, 2008, s. 139-167. 


\section{New research perspectives on books of friendship}

\section{Abstract}

The article, based on a study of books of friendship (alba amicorum) in the collection of the University Library in Wrocław, aims at presenting new research perspectives on this kind of manuscripts. The author outlines the history of books of friendship and gives an explanation on the state of research (footnotes 11 to 19), focusing on methods and undertaken topics. In the subsequent sections, alba amicorum are presented as "Objects and elements of the network," "Collections" and "Performances." The section "Objects and network elements of the network" refers to the return to materiality and the idea of the agency of things. It presents alba amicorum as material entities (not only carriers of certain information or pieces of art), as well as an active part in the development and sustaining of social networks. Each book of friendship is both a collection (of autographs, visual objects, quotes from literature) and a collectible piece. This approach was presented in the section titled "Collections." At the same time, alba amicorum gathered in museums or libraries tend to lose their performative character, presented in the last section.

Keywords: books of friendship, alba amicorum, Silesia

\section{Bibliografia}

Angermann G., Stammbücher und Poesiealben als Spiegel ihrer Zeit nach Quellen des 18.-20. Jahrhunderts aus Minden-Ravensberg, Münster 1971.

Bachmann-Medick D., Cultural turns. Nowe kierunki w naukach o kulturze, przeł. K. Krzemieniowa, Warszawa 2012.

Banet I., Szyrocki M., Die Stammbücher der Universitätsbibliothek Wrocław des 16. bis 18. Jahrhunderts, [w:] Stammbücher als kulturhistorische Quellen, red. J.-U. Fechner, München 1981, s. $65-71$.

Belting H., Bild und Kult: eine Geschichte des Bildes vor dem Zeitalter der Kunst, München 2000.

Białek E., Polnische Einträge in den Stammbüchern der Universitätsbibliothek Wroclaw, „Germanica Wratislaviensia" 68, 1985, s. 111-132.

Białek E., Das Stammbuch des Dichters Christian Hoffmann von Hoffmannswaldau, „Daphnis” 16, 1987, s. 441-456.

Białek E., Die Stammbuchsammlung in der Universitätsbibliothek Wroclaw, „Germanica Wratislaviensia" 68, 1985, s. 133-146.

Białek E., Mrozowicz W., Die Eintragungen von August Buchner in den Stammbüchern der Universitätsbibliothek Wroclaw, „Wolfenbütteler Barocknachrichten” 14, 1987, s. 68-71.

Borys A., Album Amicorum Johanna Reimanna (1544-1597). Najstarszy znany sztambuch w zbiorach Biblioteki Uniwersyteckiej we Wrocławiu, [w:] Ślaska republika uczonych, red. M. Hałub, A. Mańko-Matysiak, Dresden-Wrocław 2012, s. 109-128.

Czarnecka M., Dekorative Anwendung der Emblematik am Beispiel von Sophienthalschen Sinnbildern der Herzogin Anna Sophia von Liegnitz (1628-1666), „Daphnis” 23, 1994, z. 1, s. 1-35.

Dąbrowska-Burkhardt J., Die Textsorte Stammbuch als Vorgänger von Facebook. Eine linguistische Analyse der Stammbucheinträge aus dem 18. Jh. am Beispiel eines Grünberger album amicorum, [w:] Zwischen Kontinuität und Modernität. Metawissenschaftliche und wissenschaftliche Erkenntnisse der germanistischen Forschung in Polen, red. E. Żebrowska, M. Olpińska-Szkiełko, M. Latkowska, Warszawa 2016 (Beiträge zur Germanistik), s. 85-93. 
Delen M.-A., Frauenalben als Quelle. Frauen und Adelskultur im 16. Jahrhundert, [w:] Stammbücher des 16. Jahrhunderts, red. W. Klose, Wolfenbüttel 1989, s. 75-94.

Diedrich G., Die protestantischen Schriftaltäre des 16. und 17. Jahrhunderts in Nordwestdeutschland, Regensburg 2005.

Domańska E., Problem rzeczy we współczesnej archeologii, [w:] Rzeczy i ludzie. Humanistyka wobec materialności, red. J. Kowalewski, W. Piasek, M. Śliwa, Olsztyn 2008, s. 27-60.

Erler M.C., The Book of Hours as Album Amicorum: Jane Guildford's Book, [w:] The Social Life of Illumination. Manuscripts, Images, and Communities in the Late Middle Ages, red. J. Coleman, M. Cruse, K.A. Smith, Turnhout 2013, s. 505-536.

Grimm J., Grimm W., Stammbuch, [w:] Deutsches Wörterbuch, Leipzig 1919, t. 17, szp. 647.

Helk V., Stambøger i Det kongelige Bibliotekfør 1800, Copenhagen 1980.

Keil R., Keil R., Die deutschen Stammbücher des sechzehnten bis neunzehnten Jahrhunderts, Berlin 1893.

Kiedroń S., Neerlandicauit de kring van Martin Opitz (1597-1639), „Colloquium Neerlandicum” 12, 1994, s. 153-164.

Kohlmann T., Modelstecher, Briefmaler, Illuministen und Kartenmaler, [w:] Lexikon des alten Handwerks, red. R. Reith, München 1990, s. 164-167.

Kopytoff I., Kulturowa biografia rzeczy - utowarowienie jako proces, [w:] Badanie kultury. Elementy teorii antropologicznej, przeł. E. Klekot, red. M. Kempny, E. Nowicka, Warszawa 2003, s. 249-274.

Kurras L., Stammbücher: Freundschaft in Wort und Bild, [w:] Freundschaft. Motive und Bedeutungen, red. S. Appuhn-Radtke, E. Wipfler, München 2006, s. 261-271.

Latour B., Where Are the Missing Masses? Sociology of a Few Mundane Artefacts, [w:] Technology and Society, Building Our Sociotechnical Future, red. D. Johnson, J. Wetmore, Cambridge 2008, s. $151-180$.

Lilienthal M., Schediasma critico-literarium de philothecis varioque earundem usu et abusu, vulgo von Stamm-Büchern, Leipzig 1712.

Masner K., Die schlesischen Stammbücher und ihre künstlerische Ausschmückung, „Jahrbuch des Schlesischen Museums für Kunstgewerbe und Altertümer" 4, 1907, s. 137-170.

Michalska A., Świątynie przyjaźni. Funkcje motywu architektury i rzeźby ogrodowej w sztambuchach z przełomu XVIII i XIX wieku na przykładzie zbiorów Biblioteki Uniwersyteckiej we Wrocławiu, „Quart. Kwartalnik Instytutu Historii Sztuki Uniwersytetu Wrocławskiego” 48, 2018, nr 2, s. 22-38.

„Nicht zum Fressen, nicht zum Saufen, sondern Weisheit einzukaufen...”. Hallische Universitätsgeschichte in Stammbücher, red. A. Berhaus-Sprengel, Halle [Saale] 2017.

Nickson M., Some Early English, French and Spanish Contributions to Albums, [w:] Stammbücher des 16. Jahrhunderts, red. W. Klose, Wolfenbüttel 1989, s. 63-73.

Oszczanowski P., Gromadzki J., Theatrum vitae et mortis. Grafika, rysunek i malarstwo ksiażkowe na Ślasku w latach ok. 1550-ok. 1650, Wrocław 1995.

Rodak P., Rzeczy w kontekście pisania. O materialności dzienników osobistych, „Kultura Współczesna" 2008, nr 3, s. 100-117.

Ryantová M., Konfessionelle und konfessionsübergreifende Netzwerke in Stammbüchern der Frühen Neuzeit, „Berichte und Beiträge des Geisteswissenschaftlichen Zentrums Geschichte und Kultur Ostmitteleuropas an der Universität Leipzig” 2006, s. 314-331.

Schlueter J., The Album Amicorum and the London of Shakespeare's Time, London 2012.

Schnabel W.W., Das Stammbuch. Konstitution und Geschichte einer textsortenbezogenen Sammelform bis ins erste Drittel des 18. Jahrhunderts, Tübingen 2003.

Schwarz C., Das Album amicorum als Ort für Produktion und Rezeption von Emblemen. Überlegungen zu drei Stammbüchern (1639-1652) der Familie Maior aus Breslau, [w:] Polyvalenz und Multifunktionalität der Emblematik II, red. W. Harms, D. Peil, Frankfurt am M. 2002, s. 907-929. 
Schwarz C., Studien zur Stammbuchpraxis der Frühen Neuzeit. Gestaltung und Nutzung des Album amicorum am Beispiel eines Hofbeamten und Dichters, eines Politikers und eines Goldschmieds (etwa 1550 bis 1650), Frankfurt am M. 2002.

Tańczuk R., Ars colligendi. Kolekcjonowanie jako forma aktywności kulturalnej, Wrocław 2011.

Visser A., Escaping the reformation in the Republic of Letters: Confessional silence in latin emblem books, „Church History and Religious Culture” 88, 2008, s. 139-167.

Volger E., Katalog der Stammbücher der Stadtbibliothek Breslau, t. 1, rkps, bez daty, sygn. akc. 1967 $\mathrm{KN} 11$.

Volger E., Ueber die Sammlung von Stammbüchern (77 Stück) in der Stadtbibliothek zu Breslau, „Schlesiens Vorzeit in Bild und Schrift” 3, 1881, s. 445-475.

Wilhelm W., Das Stammbuch: Konstitution und Geschichte einer textsortenbezogenen Sammelform bis ins erste Drittel des 18. Jahrhunderts, Tübingen 2003.

Wilson B., Social Networking. The "Album amicorum" and Early Modern Public Making, [w:] Beyond the Public Sphere. Opinions Publics, Spaces in Early Modern Europe, red. M. Rospocher, Bologna 2012, s. 205-223.

Windyka T., Carl Daniel David Friedrich Bach. Jego życie i działalność. Sztambuch artysty, mps, Wrocław 1982. 